\title{
More than $A$ to $B$ : Understanding and managing visitor spatial behaviour in urban forests using public participation GIS
}

\section{Korpilo, Silviya}

2018-02-01

Korpilo , S , Virtanen , T , Saukkonen , T \& Lehvävirta, S 2018 , ' More than A to B :

Understanding and managing visitor spatial behaviour in urban forests using public

participation GIS ' , Journal of Environmental Management , vol. 207 , pp. 124-133 . https://doi.org/10.1016/j.jenvma

http://hdl.handle.net/10138/309428

https://doi.org/10.1016/j.jenvman.2017.11.020

cc_by_nc_nd

Downloaded from Helda, University of Helsinki institutional repository.

This is an electronic reprint of the original article.

This reprint may differ from the original in pagination and typographic detail.

Please cite the original version. 


\title{
More than A to B: Understanding and managing visitor spatial behaviour in urban forests using public participation GIS
}

Article submitted to Journal of Environmental Management

Pre-publication version - October 2017

Silviya Korpilo, ${ }^{\mathrm{a},{ }^{*}}$, Tarmo Virtanen ${ }^{\mathrm{a}}$, Tiina Saukkonen ${ }^{\mathrm{b}}$, Susanna Lehvävirta ${ }^{\mathrm{a}, \mathrm{c}}$

${ }^{\mathrm{a}}$ Department of Environmental Sciences, University of Helsinki, Viikinkaari 2, P.O. Box 65, FI00014, Finland

${ }^{\mathrm{b}}$ Public Works Department, City of Helsinki, Elimäenkatu 5, 00510, Helsinki, Finland

${ }^{c}$ Department of Landscape Architecture, Planning and Management, Swedish University of Agricultural Sciences, Slottsvägen 5, POB 58, SE-23053, Alnarp, Sweden

*Corresponding author: Silviya Korpilo, silviya.korpilo@helsinki.fi

\begin{abstract}
Planning and management needs up-to-date, easily-obtainable and accurate information on the spatial and social aspects of visitor behaviour in order to balance human use and impacts, and protection of natural resources in public parks. We used a web-based public participation GIS (PPGIS) approach to gather citizen data on visitor behaviour in Helsinki's Central Park in order to aid collaborative spatial decision-making. The study combined smartphone GPS tracking, route drawing and a questionnaire to examine differences between user groups in their use of formal trails, off-trail behaviour and the motivations that affect it. In our sample $(n=233)$, different activity types were associated with distinctive spatial patterns and potential extent of impacts. The density mapping and statistical analyses indicated three types of behaviour: predominantly on or close to formal trails (runners and cyclists), spatially concentrated off-trail behaviour confined to a few informal paths (mountain bikers), and dispersed off-trail use pattern (walkers and dog walkers). Across all user groups, off-trail behaviour was mainly motivated by positive attraction towards the environment such as scenic view, exploration, and viewing flora
\end{abstract}


and fauna. Study findings lead to several management recommendations that were presented to city officials. These include reducing dispersion and the spatial extent of trampling impacts by encouraging use of a limited number of well-established informal paths away from sensitive vegetation and protected habitats.

Keywords: urban forest management; public participation; recreation; spatial behaviour; off-trail use; smartphone GPS tracking 


\section{Manuscript}

\section{Introduction}

In many countries, forests are an essential part of the urban green infrastructure offering a wealth of ecosystem services that are crucial for the quality of life in modern cities (Baró et al., 2015; Faehnle et al., 2015; Tyrväinen et al., 2007). Urban forests are multiple-use green areas providing citizens with important social, health and psychological benefits. Though, intended for public use, they often experience heavy pressure from a variety of everyday outdoor activities such as dog walking, running, cycling or seeking restorative experiences (Arnberger, 2006; Hauru et al., 2012; Verlič et al., 2015). Such intensive recreational use may pose ecological and social challenges and have direct and indirect impacts on the natural resources.

Impacts of recreational activities include soil compaction and erosion, decrease in vegetation cover and tree regeneration, changes in species composition and fragmentation (Ballantyne \& Pickering, 2015b; Lehvavirta, 1999; Leung \& Marion, 2000; Malmivaara, Löfstöm, \& VanhaMajamaa, 2002). Ecological impacts that are of most concern to managers often occur in areas without formal trails (D’Antonio and Monz, 2016), however, it is difficult to predict where and when informal paths develop. Informal path systems could become significant environmental threats when spatially extensive, substantially impacted or located in sensitive habitats (Hamberg et al., 2008; Wimpey and Marion, 2011). Proliferation of informal paths may also lead to extensive trail-based fragmentation (Ballantyne, Gudes, \& Pickering, 2014; Leung, Newburger, Jones, Kuhn, \& Woiderski, 2011; Wimpey \& Marion, 2011) and great cumulative vegetation loss across the whole landscape (Ballantyne and Pickering, 2015b). In order to manage 
undesirable ecological change, it is critical to understand visitor spatial behaviour inside the area (Orellana et al., 2012) and the factors that affect it.

Recreational use consists of complex behavioural, temporal and spatial patterns (Arnberger, 2006; Wolf, Hagenloh, \& Croft, 2012). Visitor needs, values, attitudes and recreational modes vary on an individual and group level, and change over time. However, studies that analyse qualitative and spatial differences among activity groups are still relatively scarce (Andkjær and Arvidsen, 2015). This research aims to gain such insights on visitor behaviour in urban forests, while using recent developments in spatial technologies and participatory approaches.

Modern spatial technologies can provide decision-making with immediate and efficient ways to understand human spatial behaviour. Geographic Information Systems (GIS) and Global Positioning Systems (GPS) can help better plan, manage and monitor recreational use and impacts in a variety of natural resource applications (Beeco, Hallo, \& Brownlee, 2014; de Vries \& Goossen, 2002; Wolf, Wohlfart, Brown, \& Bartolomé Lasa, 2015). At the same time, the increasing integration of technology in our everyday lives provides novel opportunities for crowd-sourced research. Recent studies demonstrated the potential of smartphones in gathering detailed, useful and timely information on the spatial patterns of recreational behaviour (e.g. Doherty et al., 2014; Korpilo et al., 2017a; Santos et al., 2016). Moreover, the rapidly advancing fields of Volunteered Geographic Information (VGI) and Public Participation GIS (PPGIS) acknowledge citizens as valuable source of knowledge as they become more actively engaged in the use and production of geographic information (Brown \& Reed, 2009; Brown \& Kyttä, 2014; Feick \& Roche, 2013; Goodchild, 2007). 
This study combined VGI and PPGIS approaches to gather up-to-date data on the density, distribution and motivations of visitor use, all of which represent important variables to monitor and manage use-related impacts (Walden-Schreiner and Leung, 2013). The article presents empirical results from Helsinki's Central Park where the aim was to: 1) analyse spatial behaviour patterns of different user groups; 2) examine the spatial distribution and motivations for off-trail behaviour; and 3) outline implications for planning and management.

\section{Materials and methods}

\subsection{Study Area}

Central Park is a very intensively used recreational area in Helsinki, Finland, receiving around two million visits every year (Ilvesniemi and Saukkonen, 2015). It covers 1100 ha of land and stretches over $10 \mathrm{~km}$ in length, making it the largest single green area in the city (City of Helsinki Urban Facts, 2005). The 103 year-old park includes several nature protection areas and 700 ha of mature forest that offers rich and varied nature and wildlife (City of Helsinki Urban Facts, 2005). The terrain is diverse including forested (e.g. coniferous forests, spruce mires, groves, sparsely forested rocky outcrops) and non-forested habitats (e.g. agricultural fields, river and stream ecosystems, community gardens, fresh meadows). The most popular activities include walking, cycling, running, seeking peace and quiet, exploring nature, dog walking, commuting, and skiing during winter (Ilvesniemi and Saukkonen, 2015).

\subsection{Data collection}

This study used a web-based PPGIS tool called 'MyDynamicForest' (MDF) to gather information on visitor spatial behavior in Helsinki's Central Park (Fig.1). The website was launched in the summer of 2015 and advertised via traditional (local newspapers and radio) and 
social media. During the data collection period of six months (June to December 2015), different types of spatial (GPS-tracked and drawn routes) and questionnaire data were collected.

Participants were asked to submit their route from a recent visit in the park either in a GPS format or by drawing it digitally in the MDF website. Volunteers could submit a GPS route they had tracked using any sports tracking application on their smartphones. The aim was to make use of VGI data that were generated by volunteers for reasons other than research, often related to self-promotion or social reward e.g. to monitor personal health performance and activities, or to publically share data on everyday lives and experiences (Feick \& Roche, 2013; Oksanen, Bergman, Sainio, \& Westerholm, 2015). Yet, to avoid bias towards users of such technologies only, participants could equally draw their route over an Open Street Map basemap.

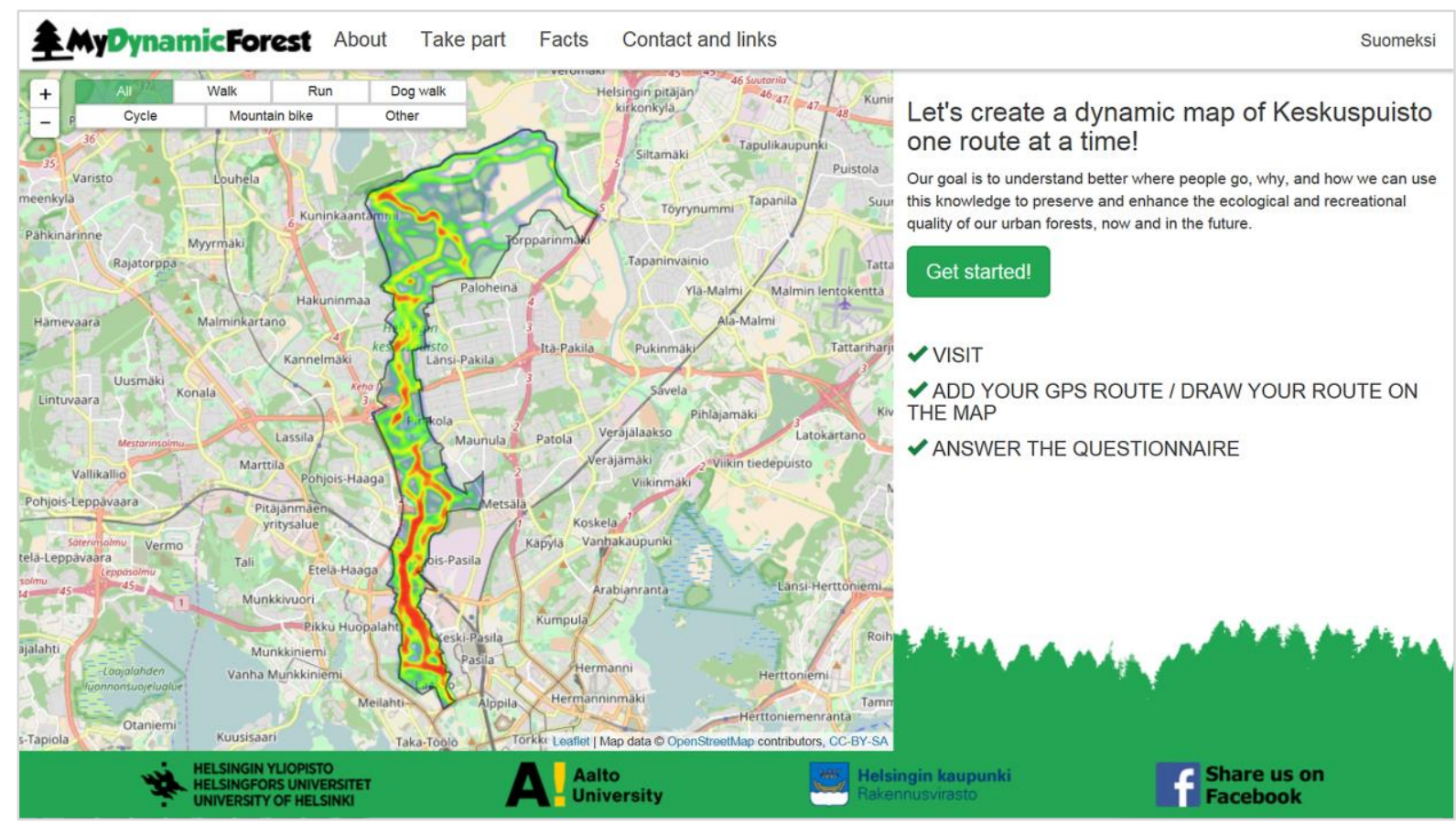

Fig. 1. MyDynamicForest website interface and study area (www.mydynamicforest.fi)

The MDF tool allowed for a dynamic representation of the collected spatial data by creating heat maps that were automatically updated after each route was added (portraying intensity of use per 
activity type or as combined). The aim was to provide instant, understandable and evolving visualizations of the data to everyone in the process of knowledge co-production. Multiple route submissions were allowed and also used in the data analysis. For each individual route, participants were asked to select a main category for their recreational activity (e.g. walking, mountain biking, running) and answer a short questionnaire (see section 2.4).

Ethical considerations related to using smartphone GPS tracking data (Meijles et al., 2014; Taczanowska et al., 2008) were carefully addressed according to guidelines by the National Advisory Board on Research Ethics in Finland. The study was conducted in accordance with the principles of informed consent (participants signed a Letter of Consent, which clarified that responses are anonymous and provided the terms and conditions of voluntary participation) and privacy protection of human subjects (avoiding possible GPS tracing of participants by analysing only in-situ movement).

\subsection{Spatial analysis}

All route tracks in a GPX format were imported in ArcGIS (v.10.2.1) and processed as two separate datasets - GPS data (line and point features) and draw data (line features). The tracks were grouped by activity into walking, dog walking, running, mountain biking, cycling and 'other' (e.g. nordic walking, roller-skating, orienteering). The 'other' tracks (in total eight) were excluded from the analysis as they represented recreational behaviour that may differ from the categorised activities, but sample sizes per activity were not sufficient for separate analyses. All tracks were cut to fit inside the borders of the study area in order to prevent tracing of human subjects to their home or work location (Korpilo et al., 2017a). Since sports tracking applications record spatial location of movement at approximately even time intervals (e.g. every second) 
(Oksanen et al., 2015), error handling of the GPS point data was performed by deleting identical GPS fixes at the same location e.g. due to users standing still. Using visual inspection, the drawn tracks were cleaned by removing routes considered too coarse for the analysis (in total seven), e.g. when a route was represented by a single straight line stretching over a large area. The GPS and draw data were not integrated due to differences in spatial accuracy and level of detail (Korpilo et al., 2017b). The drawing of routes was used as a comparative and complementary dataset.

As a first step, density mapping of the GPS and drawn tracks was conducted to serve as an overall estimate and visual representation of the location and intensity of use. Line data were used to allow for comparison between the two datasets. Following a methodology by Korpilo et al. (2017a), kernel density analysis was performed by calculating the density of GPS and drawn line features in the neighbourhood of each raster cell (10 $\mathrm{m}$ x $10 \mathrm{~m}$ raster cell size) within a search radius of $20 \mathrm{~m}$.

The next step was to conduct buffer analysis of the formal trail network in order to distinguish between GPS-tracked on-trail and off-trail spatial behaviour. The formal trail network was acquired from an official topographic database provided by National Land Survey of Finland (scale 1:10 000). A $15 \mathrm{~m}$ buffer was created around all formal trails and GPS data that were located inside the buffer was considered as on-trail, while outside the buffer - as representative of off-trail behaviour (Kidd et al., 2015; Korpilo et al., 2017a) (Fig. 2). The size of the buffer was selected based on the maximum width (up to $5 \mathrm{~m}$ ) of the formal trails in Central Park, up to $9 \mathrm{~m}$ average deviation of all on-trail tracks from the formal trail network (see Korpilo et al., 2017a, 2017b), as well as a 5-10 m typical GPS location accuracy of smartphones as indicated by previous studies (Hess et al., 2012; Menard et al., 2011; Zandbergen, 2009). 


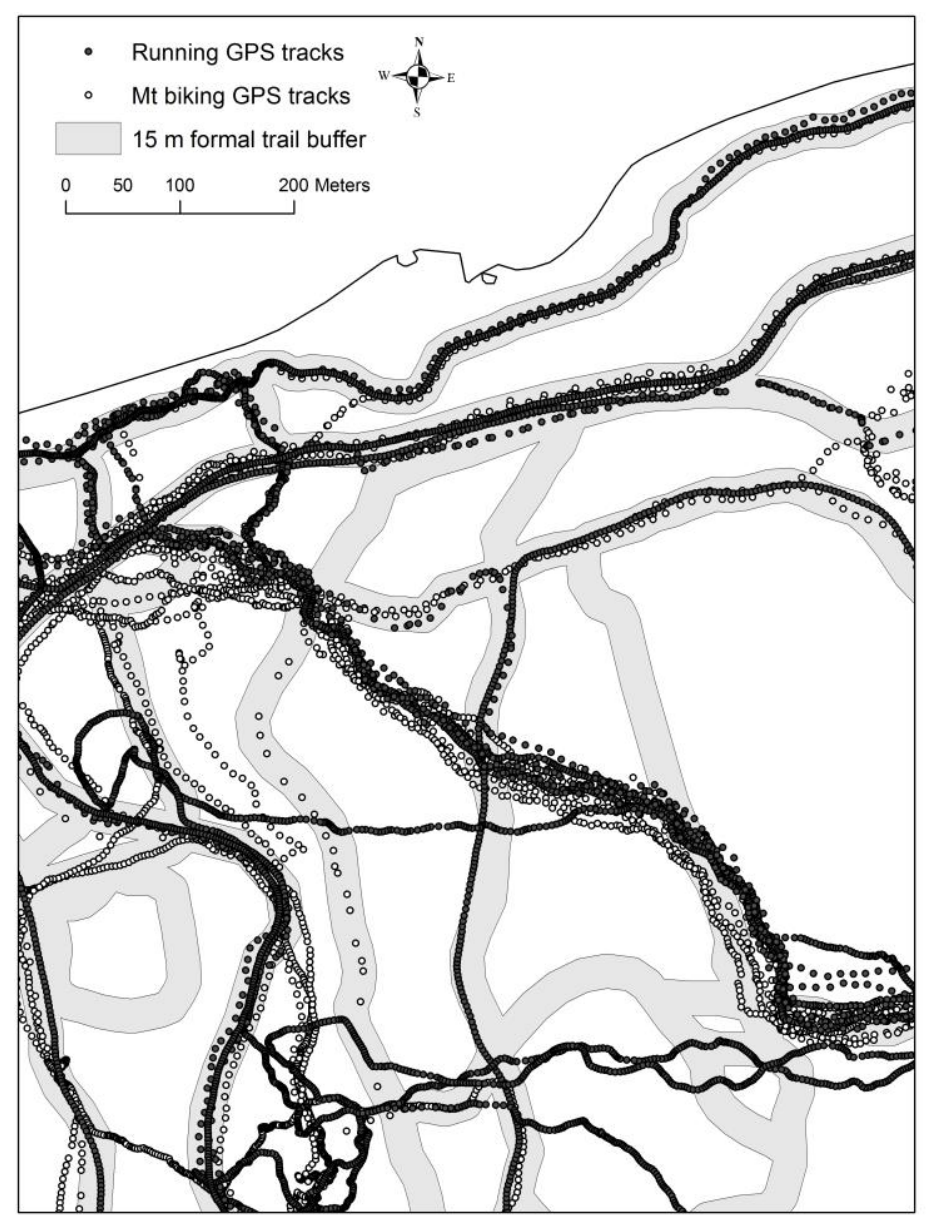

Fig. 2. An example of typical running and mountain biking GPS tracks in relation to the $15 \mathrm{~m}$ formal trail buffer. The map illustrates concentration of the two activities on a shared off-trail route.

The spatial distribution of use on formal trails and informal paths was then assessed through lineal extent metrics by calculating the total length of off-trail and on-trail GPS line features. Two approaches were used to further examine the spatial extent of off-trail use. The first investigated how far visitors dispersed away from formal trails into off-trail areas, which presents an indication for the potential extent of impacts per unit area (D'Antonio and Monz, 2016; Kidd et al., 2015). Using Proximity Analysis, the mean distance of off-trail GPS points to the edge of the $15 \mathrm{~m}$ buffered formal trails was calculated for each recreational activity. The 
second measure included assessing the overall directional distribution of off-trail use at the park scale. The Directional Distribution tool uses Euclidean (i.e. straight line) distances and a median center point to create a standard deviation ellipse, providing a visual indicator of the dispersion and direction of use (D’Antonio and Monz, 2016; Hallo et al., 2012; Kidd et al., 2015). Here distance of the off-trail GPS points to the centroid of the points was calculated based on one standard deviation, with the resulting ellipses portraying $68 \%$ of all GPS points. Comparing the size, location and orientation of the directional ellipses allows for analysing differences in distributional trends of off-trail use between recreational groups.

\subsection{Questionnaire design and analysis}

A questionnaire was used to complement the spatial mapping and provide social information behind the digital routes (see online supplementary material). The first section of the questionnaire focused on the socio-demographic background of participants (age, gender, education, occupation) and their frequency of visits. The second section included questions related to the submitted route: type of activity, the use of formal trails and informal paths, and motivations for going off-trail. Participants were asked which formal trails they used and whether they left them to use smaller paths or areas without any existing paths in the forest. The questionnaire included 14 different pre-defined motivations that were based on a typology for off-trail behaviour in national parks proposed by Wimpey \& Marion (2011). Reasons for leaving the formal trails were generally related to: 1) attraction: visitors are attracted to physical features of the environment, e.g. to view/study interesting animals and plants, enjoy a scenery, or follow an informal path; 2) exploration: to explore unknown and interesting areas; 3) avoidance: the presence of undesirable conditions on the formal trails (e.g. barriers, conflict with other users) drive visitors into off-trail areas; 4) shortcut: reducing route time or getting access 
between trails; 5) routine: following a usual route; and 6) practical reasons such as way-finding when getting lost or using the forest as toilet. Participants could additionally suggest other motivations using a free-form text. If multiple reasons were given, respondents were asked to rank them according to importance. The last question was open-ended and devoted to general comments, e.g. on personal experiences or forest management practices.

The questionnaire data were first analysed to study forest users' socio-demographics and activity (type and frequency of use). Statistical analysis in R version 3.2.2 (R Core Team 2015) was then performed to determine whether these characteristics influence route choice. Probability of offtrail use was modelled as a response (binomial error distribution) using a generalised linear mixed model (GLMM, function glmer in the lme4 package) (Bates et al., 2015). Age, gender, frequency of use, and activity type were included as predictors. In order to investigate the role of the variables in the model, i.e. whether activity type is a mediator of the background variable effects, the same GLMM analysis was performed, but excluding the variable specifying activity type (only age, gender and frequency of use were included as predictors).

Further, the motivations for getting into off-trail areas were examined. Content analysis of the 'other' free-form motivations was performed double-blind by two researchers and frequencies of mentions counted. Then, all reasons for off-trail behaviour (pre-defined and free-form) were categorised. The most frequent and most frequent primary reasons, as well as the mean number of motivations were calculated and descriptive statistics were given per recreational group.

\section{Results}

There were 233 participants in the study (45 of which submitted multiple tracks) providing in total 366 tracks (139 GPS and 227 drawn tracks) and 340 questionnaire responses related to 
summer and autumn use in Central Park. The GPS data included predominantly running (40\%), cycling (31\%) and mountain biking (22\%), with very little contribution by walkers (3\%) and dog walkers (4\%). Participants tracked their routes using 12 different sports tracking applications: e.g. Sports Tracker, Endomondo, Strava, HeiaHeia, Garmin, Runkeeper, Suunto Movescount, Attackpoint, Cycle Tracks. The draw-on-the-map tool gathered data on similar activities: cycling (32\%), running (29\%), walking (20\%), and dog walking (17\%), however, mountain bikers contributed to only $3 \%$ of the draw dataset.

Overall, $54 \%$ of participants were male and $46 \%$ female, and the majority (64\%) were in the 25 44 age group. About half (44\%) were highly educated (Master's degree or higher) and frequent park users with $46 \%$ visiting the park 2-5 times a week and $70 \%$ visiting at least once a week. The representativeness of the sample as regards background characteristics was satisfactory compared to the age and gender structure of the base population (Statistics Finland, 2015) and previous visitor surveys conducted in Central Park (Ilvesniemi and Saukkonen, 2015), although the younger age group (under 44) was slightly over-represented. GPS users were biased towards middle-aged men: $72 \%$ of the contributors were male and $46 \%$ in the age group $35-44$. The draw dataset portrayed a more equal gender and age distribution: $47 \%$ male and $53 \%$ female, $35 \%$ in the 25-34 age group, 26\%:35-44 and 21\%:45-54 age group.

\subsection{Spatial patterns of use}

The density maps depicted concentration of visitor use in the southern part of Central Park (Fig.

3). The running and cycling GPS tracks portrayed predominant on-trail behaviour (Fig. $3 \mathrm{~A}$ and B) (a similar pattern was shown by the density of drawn routes), while mountain bikers' GPS data revealed abundant off-trail use, which was concentrated on a few main informal paths (Fig. 
$3 \mathrm{C})$. Some of these informal paths were also used by runners, indicating spatial overlap between the two activities (Fig. 2). The walking and dog walking drawn routes showed a more dispersed use pattern compared to the other recreational groups, and often distributed outside the formal trail network (Fig. 3 D and E).

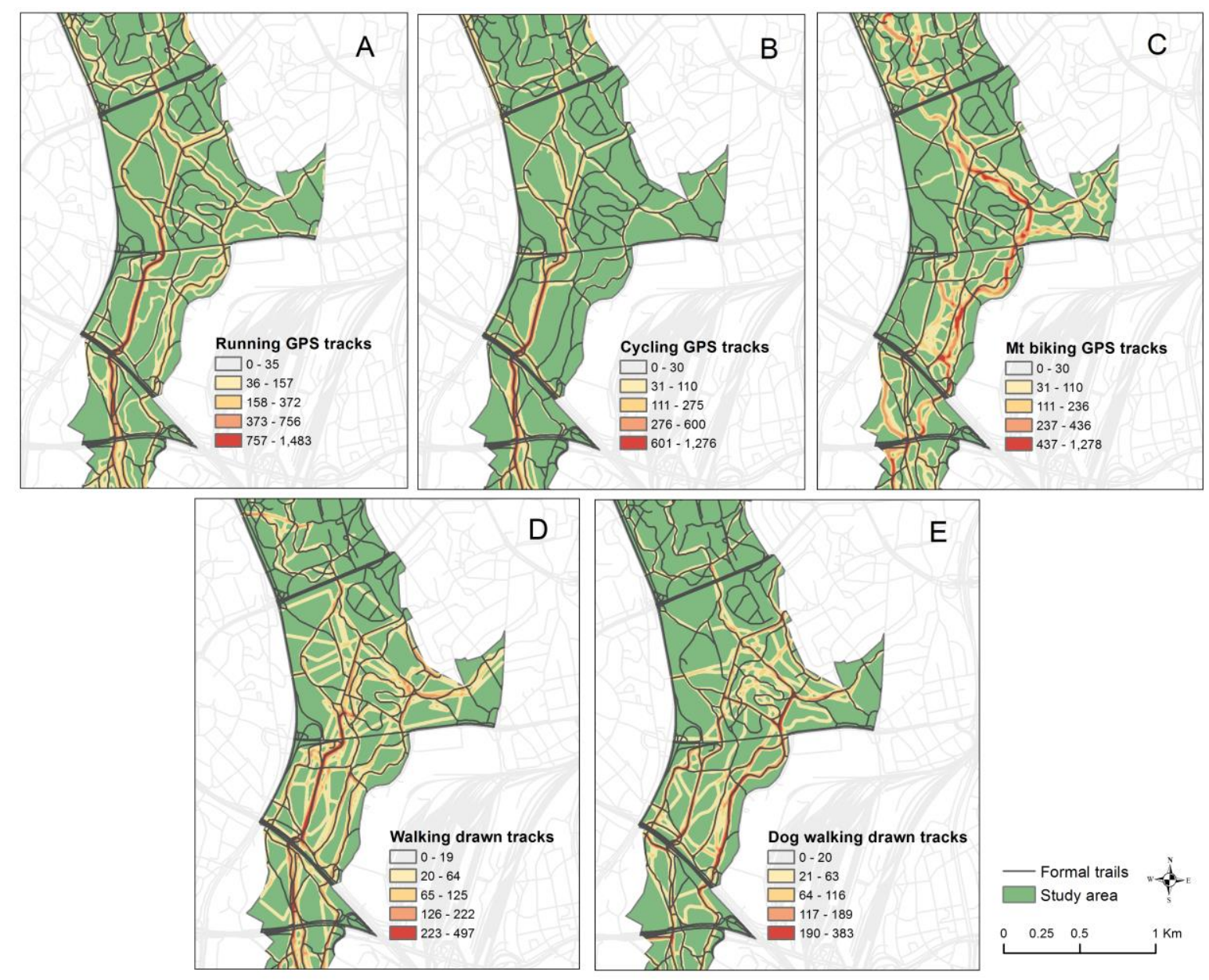

Fig. 3. Kernel density analysis (line density $\mathrm{m} / \mathrm{km}^{2}$ ) of visitor use in Helsinki's Central Park. Top maps represent density of: (A) running $(n=56)$, (B) cycling $(n=43)$, and $(C)$ mountain biking GPS tracks $(n=30)$; and bottom: (D) walking $(n=45)$ and $(E)$ dog walking $(n=38)$ drawn tracks.

Consistent with the density mapping, the results of the lineal extent calculations showed that runners and cyclists tend to follow the formal trails with only $13 \%$ of the GPS tracks located 
outside the formal trail network (Table 1). As for mountain bikers, $38 \%$ of their GPS tracks were off-trail, contributing to $66 \%$ of all observed off-trail use in the park.

\section{Table 1}

Spatial distribution of GPS-tracked visitor use per activity type in relation to the formal trail network.

*Lineal extent refers to the sum of lengths of on-trail/off-trail GPS tracks.

\begin{tabular}{lllllll}
\hline Activity & $\begin{array}{l}\text { On-trail use } \\
\text { type }\end{array}$ & $\begin{array}{l}\text { Off-trail use } \\
(\%)\end{array}$ & $\begin{array}{l}\text { On-trail } \\
\text { lineal extent } \\
(\mathbf{k m}) *\end{array}$ & $\begin{array}{l}\text { \% of } \\
\text { overall on- } \\
\text { trail use }\end{array}$ & $\begin{array}{l}\text { Off-trail } \\
\text { lineal extent } \\
(\mathbf{k m}) *\end{array}$ & $\begin{array}{l}\text { \% of } \\
\text { overall off- } \\
\text { trail use }\end{array}$ \\
\hline $\begin{array}{l}\text { Mountain } \\
\text { biking }\end{array}$ & 62.5 & 37.5 & 229.3 & 32.9 & 137.3 & 66.1 \\
Running & 86.7 & 13.3 & 337.3 & 48.5 & 51.6 & 24.8 \\
Cycling & 87.2 & 12.8 & 129.3 & 18.6 & 19.0 & 9.1 \\
\hline
\end{tabular}

In addition, mountain bikers dispersed the furthest from the $15 \mathrm{~m}$ buffered formal trails, riding an average of $27 \mathrm{~m}$ from the trails' edges. Runners dispersed an average of $17 \mathrm{~m}$ and cyclists $-8 \mathrm{~m}$ from the formal trail network (Table 2).

Table 2

Dispersion of GPS-tracked off-trail use per activity type

\begin{tabular}{llll}
\hline & $\begin{array}{l}\boldsymbol{n} \text { off-trail } \\
\text { GPS points }\end{array}$ & $\begin{array}{l}\text { Mean distance } \\
\text { from formal } \\
\text { trails } \mathbf{( m )}\end{array}$ & $\begin{array}{l}\text { Off-trail } \\
\text { directional ellipse } \\
\text { area }\left(\mathbf{k m}^{2}\right)\end{array}$ \\
\hline Mountain biking & 26906 & 27.4 & 5.09 \\
Running & 11494 & 16.9 & 7.70 \\
Cycling & 1914 & 7.6 & 8.10 \\
\hline
\end{tabular}

At the same time, the directional ellipses indicated a different off-trail dispersion pattern at the park scale (Fig. 4). Shape and orientation of the ellipses were visually similar, following the park shape in the south-north direction, however, their location and sizes varied. Mountain biking GPS off-trail points were clustered in the center of the study area with fewer observations towards the periphery. The total area of the ellipse was the smallest despite the high number of 
off-trail observations, indicating that at the landscape scale, this activity is more condensed compared to running and cycling (Table 2). Runners' off-trail GPS points were mostly located in the southern and northern parts of the park, while off-trail cycling occurred in very close proximity to formal trails, but it was widely spread across the landscape despite the low number of observations.
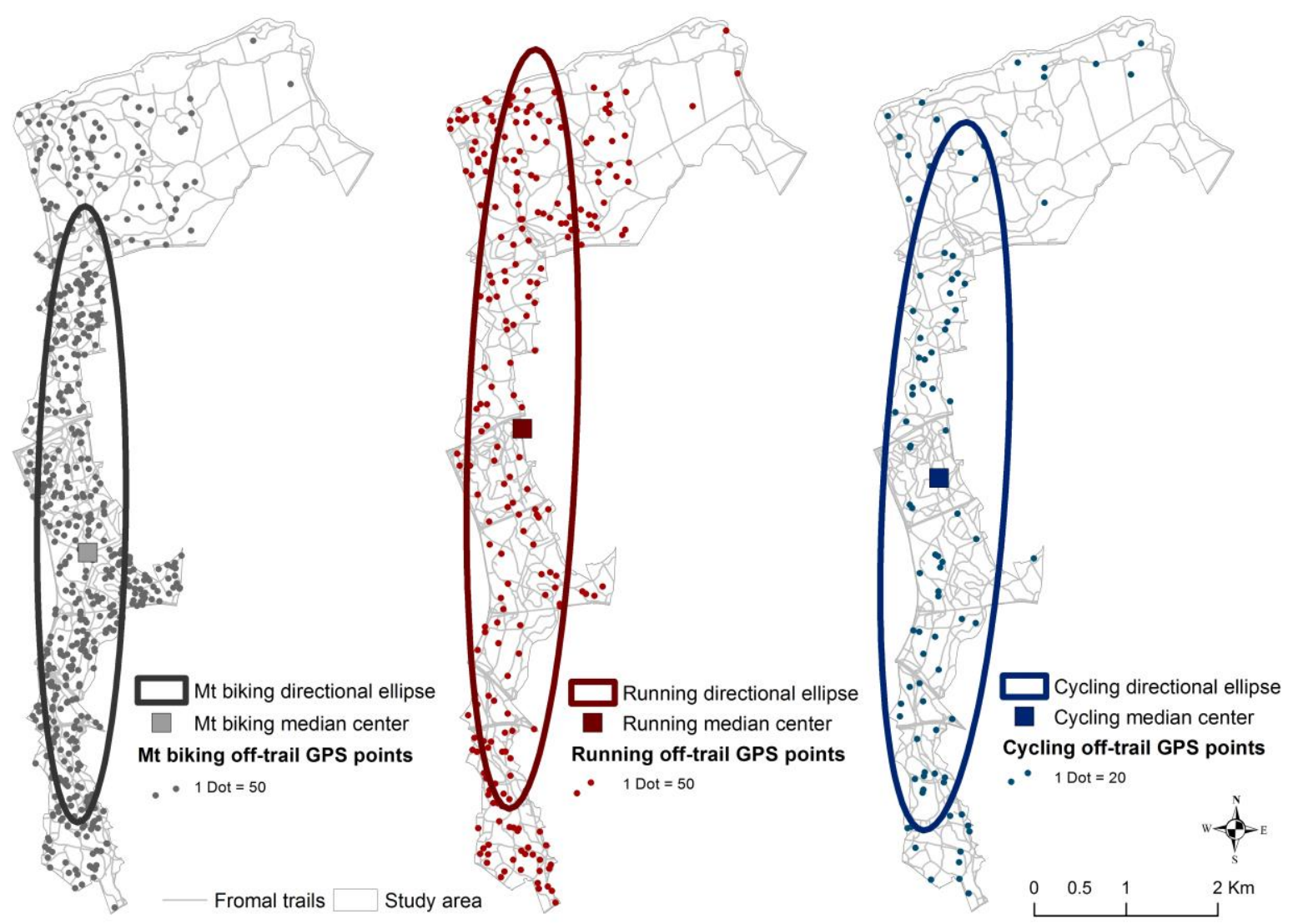

Fig. 4. Distribution trends of (from left to right) mountain biking, running and cycling off-trail use represented by directional distribution ellipses. Dot density is based on count values of offtrail GPS points over a $1 \mathrm{~km}$ grid; $1 \mathrm{dot}=50$ off-trail GPS points (mt biking and running), 1 dot $=20$ off-trail GPS points (cycling)

\subsection{Social factors affecting off-trail behaviour}


Off-trail movement was reported as part of $38 \%$ of all routes. Results from the GLMM analysis indicated that age, gender and frequency of use had no statistically significant effect on the probability of off-trail use (Table 3). Yet, a strong statistically significant effect was found for activity type, with mountain bikers being most likely to leave the formal trails, followed by dog walkers, walkers, runners and cyclists respectively. These results did not change when excluding activity type from the GLMM analysis.

\section{Table 3}

Generalised linear mixed model coefficients for probability of off-trail use with standard deviation (SD) errors and $p$ values

$*$ The intercept consists of gender $=$ female, age group $=18-24$, frequency of use $=$ once a month or less, activity $=$ cycling

\begin{tabular}{lccc}
\hline & Coefficient & SD error & $\boldsymbol{p}$ \\
\hline $\begin{array}{l}\text { Intercept } \\
\text { Gender }\end{array}$ & -3.021 & 1.322 & 0.022 \\
Male & & & \\
Age group & 0.301 & 0.326 & 0.357 \\
$25-34$ & & & \\
$35-44$ & 1.452 & 1.173 & 0.216 \\
$45-54$ & 2.137 & 1.186 & 0.072 \\
55-64 & 1.503 & 1.203 & 0.212 \\
65-74 & 2.287 & 1.280 & 0.074 \\
Frequency of use & 1.907 & 1.374 & 0.165 \\
$2-3$ times a month & & & \\
once a week & -1.040 & 0.936 & 0.267 \\
2-5 times a week & -1.326 & 0.852 & 0.120 \\
once a day & -0.624 & 0.771 & 0.419 \\
more than one time per day & -0.702 & 0.934 & 0.452 \\
Activity & -0.713 & 0.856 & 0.405 \\
Mountain biking & & & \\
Dog waking & 4.654 & 1.119 & $<.001$ \\
Walking & 2.595 & 0.533 & $<.001$ \\
Running & 2.120 & 0.507 & $<.001$ \\
& 1.295 & 0.399 & $<.001$ \\
\hline
\end{tabular}

Many respondents (64\%) reported multiple motivations for going into areas without formal trails. The motivations were classified into 15 categories based on the pre-defined and free-form 
responses (Table 4). The most common motivations for off-trail use across all groups included scenic view (16\%), using an existing informal path (13\%), exploration (11\%), and viewing flora and fauna (10\%). The analysis of respondents' frequent (Table 4) and primary motivations (Table 5) indicated that mountain bikers' off-trail behaviour was mostly motivated by attraction to informal paths and other biophysical features, whereas cyclists mentioned scenic view, exploration and practical reasons more often than any other group. Most prevalent motivations among runners included attraction to informal paths, scenic view, exploration and shortcut. Taking shortcuts was also frequently mentioned by walkers, however, they were mostly interested in a scenic view. Dog owners were predominantly driven to off-trail areas by the activity itself i.e. simply to take their dog for a walk inside the forest. Dog walkers also stated to follow routine routes and avoid interactions with others. 


\section{Table 4}

Motivations for off-trail behaviour in Central Park based on pre-defined questionnaire statements and free-form responses. Motivations are presented as percentage of the total number of motivations per recreational group (including multiple responses).

* Overall proportion (\%) of a motivation across all responses.

\begin{tabular}{|c|c|c|c|c|c|c|c|}
\hline Motivations & Description & $\begin{array}{l}\text { Mountain } \\
\text { biking }\end{array}$ & $\begin{array}{l}\text { Dog } \\
\text { walking }\end{array}$ & Walking & Running & Cycling & All * \\
\hline \multicolumn{8}{|l|}{ Pre-defined } \\
\hline Scenic view & $\begin{array}{l}\text { To get to a scenic } \\
\text { view/interesting area }\end{array}$ & 18.6 & 8.9 & 19.0 & 14.0 & 20.7 & 15.8 \\
\hline Informal path & $\begin{array}{l}\text { There was a small interesting } \\
\text { path created by others }\end{array}$ & 20.3 & 5.4 & 12.1 & 17.5 & 6.9 & 13.1 \\
\hline Exploration & To explore the environment & 10.2 & 7.1 & 12.1 & 10.5 & 20.7 & 11.2 \\
\hline Flora/fauna & To view flora/fauna & 8.5 & 10.7 & 12.1 & 7.0 & 10.3 & 9.7 \\
\hline $\begin{array}{l}\text { Biophysical } \\
\text { feature }\end{array}$ & $\begin{array}{l}\text { To go to an interesting } \\
\text { feature (e.g. hill/stone/fallen } \\
\text { tree/water body) }\end{array}$ & 18.6 & 5.4 & 5.2 & 5.3 & 3.4 & 8.1 \\
\hline Routine & To take a usual route & 6.8 & 12.5 & 6.9 & 7.0 & 0.0 & 7.3 \\
\hline Shortcut & To take a shortcut & 0.0 & 7.1 & 13.8 & 10.5 & 3.4 & 7.3 \\
\hline Dog walk & To lead/follow the dog & 0.0 & 25.0 & 1.7 & 0.0 & 0.0 & 5.8 \\
\hline $\begin{array}{l}\text { Avoiding } \\
\text { others }\end{array}$ & To avoid other people/dogs & 3.4 & 12.5 & 5.2 & 1.8 & 0.0 & 5.0 \\
\hline Path surface & $\begin{array}{l}\text { To avoid poor } \\
\text { surface/obstacle }\end{array}$ & 5.1 & 5.4 & 1.7 & 3.5 & 10.3 & 4.6 \\
\hline Practical & $\begin{array}{l}\text { Accidentally due to getting } \\
\text { lost; toilet break }\end{array}$ & 0.0 & 0.0 & 0.0 & 7.0 & 13.8 & 3.1 \\
\hline Plant picking & $\begin{array}{l}\text { To pick flowers/plants/ } \\
\text { mushroom/berries }\end{array}$ & 0.0 & 0.0 & 3.4 & 3.5 & 6.9 & 2.3 \\
\hline \multicolumn{8}{|l|}{ Other } \\
\hline Activity & $\begin{array}{l}\text { Off-trail dependent activities } \\
\text { (e.g. geocaching) }\end{array}$ & 3.4 & 0.0 & 1.7 & 8.8 & 0.0 & 3.1 \\
\hline Variation & $\begin{array}{l}\text { To provide variation in the } \\
\text { trails/activity }\end{array}$ & 3.4 & 0.0 & 3.4 & 1.8 & 3.4 & 2.3 \\
\hline Emotions & $\begin{array}{l}\text { Feelings of fun/joy/real } \\
\text { forest }\end{array}$ & 1.7 & 0.0 & 1.7 & 1.8 & 0.0 & 1.2 \\
\hline Total $n$ & & 59 & 56 & 58 & 57 & 29 & 259 \\
\hline
\end{tabular}

In addition, when comparing self-reported off-trail behaviour between recreational groups, positive relationship between several parameters could be observed (Table 5). The higher the statistical probability (based on activity type) to engage in off-trail behaviour (Table 3 ), the 
higher were the percentage of self-reported off-trail use and the mean number of motivations, the latter with a change in order between running and cycling (Table 5).

\section{Table 5}

Description of off-trail use by activity type based on self-reported behaviour in the questionnaire. The activities are ordered by statistically significant effect on the probability of off-trail use (highest to lowest) based on results from the GLMM analysis (Table 3).

* Self-reported off-trail use refers to the share of tracks reported to include off-trail movement.

\begin{tabular}{lllll}
\hline Activity type & $\begin{array}{l}\text { Self-reported off- } \\
\text { trail use (\%)* }\end{array}$ & $\begin{array}{l}\text { Mean } \boldsymbol{n} \\
\text { motivations }\end{array}$ & $\begin{array}{l}\text { Most frequent } \\
\text { motivation }\end{array}$ & $\begin{array}{l}\text { Most frequent primary } \\
\text { motivation }\end{array}$ \\
\hline $\begin{array}{l}\text { Mountain } \\
\text { biking }\end{array}$ & 90.0 & 3.3 & informal path & informal path \\
Dog walking & 61.8 & 2.7 & dog walk & dog walk \\
Walking & 56.4 & 2.6 & scenic view & scenic view \\
Running & 36.0 & 1.9 & informal path & scenic view/shortcut \\
Cycling & 14.3 & 2.0 & scenic view/exploration & exploration \\
\hline
\end{tabular}

\section{Discussion}

\subsection{Differences in spatial patterns of visitor use}

The density mapping and statistical analyses indicated three distinctive patterns of visitor behaviour in Central Park: predominantly on or close to formal trails (runners and cyclists), spatially concentrated off-trail use confined to a few informal paths (mountain bikers), and dispersed off-trail use pattern (walkers and dog walkers). Further, our findings pointed out that the spatial extent of off-trail use and impacts may vary at different scales (site and landscape level) according to the activity type. Understanding these differences can help facilitate multiscale decision-making that is context and user group specific.

Mountain bikers contributed to $66 \%$ of all GPS-tracked off-trail use in the park, yet, they portrayed the most spatially confined behaviour among all user groups. Mountain bikers showed the highest statistical probability to leave the formal trails and travelled the furthest away from 
them (on average $27 \mathrm{~m}$ ), mainly motivated to reach and follow already existing informal paths. In addition, there was high concentration of off-trail mounting biking in the central part of the study area (see Fig. 5). Since this activity group portrays spatial and social preference towards specific routes, simple indirect management techniques, such as providing guide maps (online and on-site) and trail signage, could be implemented to further encourage the use of selfestablished trails. However, management strategies should adequately consider environmental characteristics and sensitivity to trampling since mountain biking could lead to path widening and heavy wear on the forest floor vegetation on intensively used trails (Korpilo et al., 2017a). While these impacts may vary depending on e.g. riding style and site-specific ecological conditions, it has been shown that mountain biking can lead to significant vegetation loss due to the creation and self-modification of informal paths (Newsome and Davies, 2009). An effective and easy-to-use mapping technique like smartphone GPS tracking can help determine and monitor emerging and changing informal use, and inform proactive management where impacts occur (Korpilo et al., 2017a).

Runners in turn, dispersed on average $17 \mathrm{~m}$ from the designated trails and widely across the park as a whole. Gobster (2005), and Wolf and Wohfart (2014), who studied the use of urban trails in Chicago, USA, and formal recreational trails in two national parks in Australia, found that runners were mostly health-motivated and regularly used the same trails rather than diversifying their route choices. In this study, runners displayed a varied spatial behaviour pattern and stated diversity of reasons for going off-trail including leisure-oriented (scenic view, exploring the environment) and utilitarian motivations (shortcuts).

Cyclists mostly stayed on or in very close proximity to formal trails (on average within $8 \mathrm{~m}$ from the trail's edge). Only $13 \%$ of the cycling GPS tracks were located outside the formal trail 
network, however, their distribution was widespread across the landscape and exhibited no clear spatial pattern. This random 'stepping off' from formal trails at various locations could be explained by cyclists' reported desire to explore the environment, reach a scenic view or view flora and fauna. In general, it may be challenging and even undesirable for managers to restrain visitor desire to 'roam' in public parks. Instead, providing explicit information on why it is important to stay on paths (Park et al., 2008), in combination with strategically placing and allowing natural barriers (e.g. fallen logs and thickets) (Coppes and Braunisch, 2013; Hauru et al., 2012; Lehvavirta, 1999) to limit 'stepping off' behaviour, could be an effective practice at sites where recreation-related damage is not acceptable.

An important limitation in this study is that the actual spatial behaviour of walkers and dog walkers could not be analysed due to insufficient GPS data. Although the drawn routes represent recalled use and are less accurate and detailed than the GPS tracks (Korpilo et al., 2017b), they still offer valuable insights on overall spatial patterns and concentration of use. In the case of walkers and dog walkers, the draw data pointed out important clues to managers as regards the most intensively used areas. The density analysis also suggested a dispersed off-trail use pattern for these user groups. Further research targeting dispersed activities is needed since their impacts across the whole landscape may be more damaging than the severe but localised impacts of concentrated off-trail use (e.g. that of mountain bikers) (Ballantyne et al., 2014). It should be recognized that in areas with restrictions on off-trail use, a bias towards socially acceptable behaviour in the self-reported dataset may occur. However, Central Park is a public urban forest and off-trail use is not restricted or disapproved in any way, neither are there any sanctions for such behaviour, therefore, we do not anticipate a significant bias in this study.

\subsection{What motivates off-trail use in urban forests?}


Off-trail use is a key component of recreational behaviour in Helsinki's Central Park as around one fourth of the GPS tracks were distributed outside the formal trail network and $38 \%$ of all visitor tracks (GPS and drawn) were reported by respondents as containing off-trail movement. Similar to findings by Park et al. (2008) for walking off-trail in national parks, we found that demographics of visitors (age and gender) were not significant factors affecting off-trail behaviour, and neither was the frequency of use. Although background characteristics (age and gender) may generally influence the choice of recreational activity, in our study, activity type did not play a role as a mediator of the background variable effect and in fact, it was the strongest and only statistically significant factor associated with the use of informal paths. This indicates that the type of activity greatly impacts off-trail behaviour leading to e.g. differences in the spatial range of dispersion (Walden-Schreiner and Leung, 2013) or the spatial arrangement of informal trails (i.e. trails used for particular activities and motives) (Wimpey and Marion, 2011). Another important factor is motivation. Many respondents (64\%) reported multiple motivations for off-trail use and the number of motivations and probability of leaving the formal trails were positively associated at the activity group level. This shows that informal paths are created and used for multiple reasons that vary on an individual (Wimpey and Marion, 2011) and user group level. While it may be unfeasible to integrate the whole range of visitor motivations and demands (which may be often conflicting), knowledge about main motivational patterns could be of great benefit to planners and managers. Based on the results of this study, we identify several motivational patterns of visitor behaviour in urban forests: attraction towards the environment (here being the strongest), informal paths as pull factors, utilitarian, and avoidance behaviour (here low). 
As in previous studies (Hockett et al., 2010; Park et al., 2008; Wimpey and Marion, 2011), scenic view, exploration, flora and fauna, and biophysical features as main motivations for offtrail movement in Central Park imply that most of the diversions from formal trails are due to visitors wanting to experience nature. Therefore, management should involve users to design interventions with minimal disturbance to the naturalness and scenery of the area.

Taking a shortcut and following a routine route were also frequent motivations for off-trail movement (14.6\% of responses). This suggests that off-trail behaviour in urban forests is also influenced by utilitarian reasons such as using informal paths for the daily walking of a dog or commuting (Gobster, 2005; Shafer et al., 2000). It is important to recognise utilitarian activities as the management implications may be very different from other types of use. For example, shortcuts are often created to provide access between formal trails or to avoid poor surface (e.g. muddy features or moist vegetation). Implementing subtle re-surfacing on and between popular trails (e.g. by placing duckboards) could facilitate their usage, limit path widening and lessen the spatial dispersion of trampling impacts.

In Central Park, many off-trail users were attracted to already existing informal paths (13.1\% of responses), especially mountain bikers (20.3\%) and runners (17.5\%). This supports past research showing that probability for leaving the formal trails increases significantly when informal paths are already available (Coppes and Braunisch, 2013; Hockett et al., 2010), and the more they are used, the more visible and potentially attractive they become to different user groups (Brooks and Titre, 2003; Wimpey and Marion, 2011).

In general, there was a relatively low avoidance pattern among recreational users in this study (5\% of responses) compared to e.g. Arnberger (2012) who examined the increased use of 
Wienerberg recreational area in Vienna, Austria, and found that approximately one third of the visitors changed their routes within the green area to avoid crowding. Although the yearly number of visitors in both recreational areas is relatively similar, the size of our study site is approximately ten times bigger than Arnberger's study site in Vienna, which may be an explanation for the currently low need for avoidance behaviour among park visitors. However, dog walkers stated to avoid others probably due to perceived negative outcomes of interactions with other users. The lower crowding tolerance of this group may mean that they are more sensitive to increase in use levels (Arnberger and Haider, 2005; Wolf and Wohlfart, 2014) and in areas with high density of use, they could possibly disperse more.

This study focused on the social factors that affect off-trail behaviour. Future research could investigate whether and how different environmental features e.g. topography, vegetation and recreational infrastructure (see Coppes and Braunisch, 2013) influence off-trail use. In addition, qualitative methods such as in-depth interviews could be used to target specific user groups and gain deeper understanding of their motivations, behaviour and possible conflicts.

\subsection{Managing visitor spatial behaviour in off-trail areas}

Helsinki's Central Park exemplifies the need to monitor the spatial extent of off-trail impacts in urban forests, and, especially in sensitive or protected habitats, to take measures to limit these impacts (Ballantyne and Pickering, 2015a; Lehvävirta et al., 2014). Based on this study and previous ecological findings, we offer several practical recommendations for managing visitor spatial behaviour in off-trail areas:

(1) Develop methods for encouraging use of a limited number of existing well-established informal paths in order to minimise cumulative spatial impacts in areas with high 
ecological value (Ballantyne and Pickering, 2015b). As ecological impacts can extend several meters away from the paths (Hamberg et al., 2008), and as there are users that seek for peace and privacy, we advise managers to determine a range of acceptable path density that is context-specific. Subtle management interventions should be implemented to limit path widening and dispersion of use where this range is exceeded.

(2) Continuously use participatory techniques in order to reconcile resource conservation and high demand for quality nature experiences of visitors. For example, mountain bikers' off-trail GPS tracks could be used as an accurate spatial foundation for planning and formalization of routes to meet mountain bikers' needs. Effective planning of mountain biking trails will integrate environmental sensitivity and co-design, incorporating users' preferences, expectations and local knowledge (Goeft and Alder, 2001). However, managers should also consider the multiple-use and multiple-motivation of informal paths. This is important as increased use levels of different activities at the same spatial and temporal scales could potentially induce conflicts (Santos et al., 2016). Involving users at an early stage can reduce or prevent incompatible uses and lead to better planning and management outcomes (Moore, 1994; Newsome and Davies, 2009).

(3) Investigate the effect of new strategies on visitor spatial behaviour (e.g. whether designating mountain biking trails via co-design would lead to more spatially concentrated use) and refine practices based on those findings as part of adaptive management.

At the time of writing this article, the above issues were being addressed by Helsinki City officials as part of the new nature management plan for Central Park.

\section{Conclusions}


This study used a web-based PPGIS tool called MyDynamicForest that combined smartphone GPS tracking, route drawing and a questionnaire to gather rich and versatile citizen information for planning and management purposes. The data were easy to acquire and offered sufficient detail for a range of analyses such as exploring overall spatial patterns of different user groups and examining off-trail behaviour - its spatial distribution and the social factors that affect it.

Although the utilization of VGI and PPGIS in research can pose challenges related to data heterogeneity, spatial accuracy and difficulties in assessing data quality (Brovelli et al., 2016; Brown et al., 2014), such data could be highly relevant when the aim is to encourage collaboration between citizens and land use planners (Brown \& Kyttä, 2014) or facilitate knowledge exchange between managers and different recreational groups. Effective environmental management requires understanding of the spatial and social aspects of visitor use in order to balance between recreational and conservation demands (Beeco and Brown, 2013; Cole and Daniel, 2003; Orellana et al., 2012). The use of participatory web platforms like MyDynamicForest could offer feasible ways to regularly collect user data at various spatial and temporal scales. 


\section{Acknowledgements}

This research has been funded by Maj and Tor Nessling Foundation and the Finnish National Agency for Education (CIMO). Development of MyDynamicForest tool was funded by the Faculty of Biological and Environmental Sciences, University of Helsinki. We would like to thank Markettä Kyttä and Kamyar Hasanzadeh from Aalto University for their advice on the design, and to Claus Nurro for developing the tool. We are also very thankful to Johan Kotze (University of Helsinki) and Juha Heikkinen (Finnish Forest Research Institute) for their valuable help with the statistical analysis.

\section{References}

Andkjær, S., Arvidsen, J., 2015. Places for active outdoor recreation - A scoping review. J. Outdoor Recreat. Tour. 12, 25-46. doi:10.1016/j.jort.2015.10.001

Arnberger, A., 2006. Recreation use of urban forests: An inter-area comparison. Urban For. Urban Green. 4, 135-144. doi:10.1016/j.ufug.2006.01.004

Arnberger, A., Haider, W., 2005. Social effects on crowding preferences of urban forest visitors. Urban For. Urban Green. 3, 125-136. doi:10.1016/j.ufug.2005.04.002

Arnberger, A., 2012. Urban Densification and Recreational Quality of Public Urban Green Spaces-A Viennese Case Study. Sustainability, 4, 703-720. doi:10.3390/su4040703

Ballantyne, M., Gudes, O., Pickering, C.M., 2014. Recreational trails are an important cause of fragmentation in endangered urban forests: A case-study from Australia. Landsc. Urban Plan. 130, 112-124. doi:10.1016/j.landurbplan.2014.07.004

Ballantyne, M., Pickering, C.M., 2015a. The impacts of trail infrastructure on vegetation and soils: Current literature and future directions. J. Environ. Manage. 164, 53-64. doi:10.1016/j.jenvman.2015.08.032

Ballantyne, M., Pickering, C.M., 2015b. Differences in the impacts of formal and informal recreational trails on urban forest loss and tree structure. J. Environ. Manage. 159, 94-105. doi:10.1016/j.jenvman.2015.05.007

Baró, F., Haase, D., Gómez-Baggethun, E., Frantzeskaki, N., 2015. Mismatches between ecosystem services supply and demand in urban areas: A quantitative assessment in five European cities. Ecol. Indic. 55, 146-158. doi:10.1016/j.ecolind.2015.03.013

Bates, D., Mächler, M., Bolker, B.M., Walker, S.C., 2015. Fitting linear mixed-effects models using lme4. J. Stat. Softw. 67, 1-48. doi:10.18637/jss.v067.i01

Beeco, J.A., Brown, G., 2013. Integrating space, spatial tools, and spatial analysis into the human 
dimensions of parks and outdoor recreation. Appl. Geogr. 38, 76-85.

doi:10.1016/j.apgeog.2012.11.013

Beeco, J.A., Hallo, J.C., Brownlee, M.T.J., 2014. GPS Visitor Tracking and Recreation Suitability Mapping: Tools for understanding and managing visitor use. Landsc. Urban Plan. 127, 136-145. doi:10.1016/j.landurbplan.2014.04.002

Brooks, J.J., Titre, J.P., 2003. A multi-method assessment of recreation impacts at Rocky Mountain National Park. Phase I Final Project Report for The National Park Service. Fort Collins: Colorado State University, Department of Natural Resource Recreation and Tourism. doi: 10.13140/2.1.1720.1448

Brovelli, M.A., Minghini, M., Zamboni, G., 2016. Public participation in GIS via mobile applications. SPRS J. Photogramm. Remote Sens..114, 306-315. doi:10.1016/j.isprsjprs.2015.04.002

Brown, G., Kyttä, M., 2014. Key issues and research priorities for public participation GIS (PPGIS): A synthesis based on empirical research. Appl. Geogr. 46, 126-136. doi:10.1016/j.apgeog.2013.11.004

Brown, G., Weber, D., Bie, K. De, 2014. Is PPGIS good enough ? An empirical evaluation of the quality of PPGIS crowd- sourced spatial data for conservation planning. Land Use Policy 43, 1-35.doi: 10.1016/j.landusepol.2014.11.014

Brown, G., Reed, P., 2009. Public participation GIS: A new method for use In national forest planning. For. Sci. 55, 166-182.doi: 10.1016/j.landurbplan.2011.03.003

City of Helsinki Urban Facts, 2005. Nature, Recreation and Sport in Helsinki (Web publications 2005:23). Available from http://www.hel.fi/hel2/Tietokeskus/julkaisut/pdf/05_06_27_ranto_vj23.pdf.

Cole, D.N., Daniel, T.C., 2003. The science of visitor management in parks and protected areas: from verbal reports to simulation models. J. Nat. Conserv. 11, 269-277. doi:10.1078/16171381-00058

Coppes, J., Braunisch, V., 2013. Managing visitors in nature areas: where do they leave the trails? A spatial model. Wildlife Biol. 19, 1-11. doi:10.2981/12-054

D’Antonio, A., Monz, C., 2016. The influence of visitor use levels on visitor spatial behavior in off-trail areas of dispersed recreation use. J. Environ. Manage. 170, 79-87. doi:10.1016/j.jenvman.2016.01.011

de Vries, S., Goossen, M., 2002. Modelling recreational visits to forests and nature areas. Urban For. Urban Green. 1, 5-14. doi:10.1078/1618-8667-00002

Doherty, S.T., Lemieux, C.J., Canally, C., 2014. Tracking human activity and well-being in natural environments using wearable sensors and experience sampling. Soc. Sci. Med. 106, 83-92. doi:10.1016/j.socscimed.2014.01.048

Faehnle, M., Söderman, T., Schulman, H., Lehvävirta, S., 2015. Scale-sensitive integration of ecosystem services in urban planning. GeoJournal. doi:10.1007/s10708-014-9560-z

Feick, R., Roche, S., 2013. eick, R., \& Roche, S. (2013). Understanding the Value of VGI, in: Sui, D., Elwood, S., \& Goodchild, M. (Eds.), Crowdsourcing Geographic Knowledge: Volunteered Geographic Information (VGI) in Theory and Practice, Dordrecht: Springer 
Netherlands. doi:10.1007/978-94-007-4587-2

Gobster, P.H., 2005. Recreation and Leisure Research from an Active Living Perspective:

Taking a Second Look at Urban Trail Use Data. Leis. Sci. 27, 367-383.

doi:10.1080/01490400500225674

Goeft, U., Alder, J., 2001. Sustainable Mountain Biking: A Case Study from the Southwest of Western Australia. J. Sustain. Tour. 9, 193-211. doi:10.1080/09669580108667398

Goodchild, M.F., 2007. Citizens as sensors: The world of volunteered geography. GeoJournal 69, 211-221. doi:10.1007/s10708-007-9111-y

Hallo, J.C., Beeco, J.A., Goetcheus, C., McGee, J., McGehee, N.G., Norman, W.C., 2012. GPS as a Method for Assessing Spatial and Temporal Use Distributions of Nature-Based Tourists. J. Travel Res. 51, 591-606. doi:10.1177/0047287511431325

Hamberg, L., Lehvävirta, S., Minna, M.-L., Rita, H., Kotze, D.J., 2008. The effects of habitat edges and trampling on understorey vegetation in urban forests in Helsinki, Finland. Appl. Veg. Sci. 11, 83-98. doi:10.3170/2007-7-18428

Hauru, K., Niemi, A., Lehvävirta, S., 2012. Spatial distribution of saplings in heavily worn urban forests: Implications for regeneration and management. Urban For. Urban Green. 11, 279289. doi:10.1016/j.ufug.2012.03.004

Hess, B., Farahani, A.Z., Tschirschnitz, F., von Reischach, F., 2012. Evaluation of fine-granular GPS tracking on smartphones. Proc. First ACM SIGSPATIAL Int. Work. Mob. Geogr. Inf. Syst. doi:10.1145/2442810.2442817

Hockett, K., Clark, A., Leung, Y.F., Marion, J. L., Park, L., 2010. Deterring off-trail hiking in Protected Natural Areas: Evaluating Options with Surveys and Unobtrusive Observation. Virginia Tech College of Natural Resources, Forestry/Recreation Resources Management. doi: 10.13140/2.1.1595.3608

Ilvesniemi, S., Saukkonen, T., 2015. Keskuspuiston käyttäjätutkimus 2007-2009 (Central Park visitor survey 2007-2009). City of Helsinki: Public Works Department. Available from: http://www.hel.fi/www/hkr/fi/palvelut/suunnitelmat/keskuspuisto

Kidd, A.M., Monz, C., D’Antonio, A., Manning, R.E., Reigner, N., Goonan, K. a., Jacobi, C., 2015. The effect of minimum impact education on visitor spatial behavior in parks and protected areas: An experimental investigation using GPS-based tracking. J. Environ. Manage. 162, 53-62. doi:10.1016/j.jenvman.2015.07.007

Korpilo, S., Virtanen, T., Lehvävirta, S., 2017a. Smartphone GPS tracking: Inexpensive and efficient data collection on recreational movement. Landsc. Urban Plan. 157, 608-617. doi:10.1016/j.landurbplan.2016.08.005

Korpilo, S., Virtanen, T., Lehvävirta, S., 2017b. MyDynamicForest : citizen data on spatial patterns and motives of recreational use in Helsinki's Central Park, in: Bregt, A., Sarjakoski, T., Lammeren, R. van, Rip, F. (Eds.), Proc. 20th AGILE Conference on Geographic Information Science. Wageningen, the Netherlands. Available from: https://agile-online.org/index.php/conference/proceedings/proceedings-2017

Lehvavirta, S., 1999. Structural elements as barriers against wear in urban woodlands. Urban Ecosyst. 3, 45-56. doi:10.1023/A:1009513603306 
Lehvävirta, S., Vilisics, F., Hamberg, L., Malmivaara-lämsä, M., Kotze, D.J., 2014. Urban Forestry \& Urban Greening Fragmentation and recreational use affect tree regeneration in urban forests. Urban For. Urban Green. 13, 869-877. doi:10.1016/j.ufug.2014.10.003

Leung, Y.F., Marion, J.L., 2000. Recreation impacts and management in wilderness: A state-ofknowledge review. USDA For. Serv. Proc. 15, 23-48. doi:10.1098/rspb.2005.3251

Leung, Y.F., Newburger, T., Jones, M., Kuhn, B., Woiderski, B., 2011. Developing a monitoring protocol for visitor-created informal trails in Yosemite National Park, USA. Environ. Manage. 47, 93-106. doi:10.1007/s00267-010-9581-4

Malmivaara, M., Löfstöm, I., Vanha-Majamaa, I., 2002. Anthropogenic effects on understorey vegetation in Myrtillus type urban forests in southern Finland. Silva Fenn. 36, 367-381. doi: 10.1016/j.compenvurbsys.2013.07.005

Meijles, E.W., de Bakker, M., Groote, P.D., Barske, R., 2014. Analysing hiker movement patterns using GPS data: Implications for park management. Comput. Environ. Urban Syst. 47, 44-57. doi:10.1016/j.compenvurbsys.2013.07.005

Menard, T., Miller, J., Nowak, M., Norris, D., 2011. Comparing the GPS capabilities of the Samsung Galaxy S, Motorola Droid X, and the Apple iPhone for vehicle tracking using FreeSim-Mobile. Proc. IEEE Conf. Intell. Transp. Syst. Proceedings, ITSC 985-990. doi:10.1109/ITSC.2011.6083141

Moore, R. L. (1994). Conflicts on multiple use trails: Synthesis of the Literature and State of the Practice. Federal Highway Administration Report No. FHWA-PD-94-031. Available from: http://www.americantrails.org/resources/ManageMaintain/MooreConflictMgmt.htm

Newsome, D., Davies, C., 2009. A case study in estimating the area of informal trail development and associated impacts caused by mountain bike activity in John Forrest National Park, Western Australia. J. Ecotourism 8, 237-253. doi:10.1080/14724040802538308

Oksanen, J., Bergman, C., Sainio, J., Westerholm, J., 2015. Methods for deriving and calibrating privacy-preserving heat maps from mobile sports tracking application data. JTRG 48, 135144. doi:10.1016/j.jtrangeo.2015.09.001

Orellana, D., Bregt, A.K., Ligtenberg, A., Wachowicz, M., 2012. Exploring visitor movement patterns in natural recreational areas. Tour. Manag. 33, 672-682.

doi:10.1016/j.tourman.2011.07.010

Park, L.O., Manning, R.E., Marion, J.L., Lawson, S.R., Jacobi, C., 2008. Managing Visitor Impacts in Parks : A Multi-Method Study of the Effectiveness of Alternative Management Practices. J. Park Recreat. Admi. 26, 97-121.

Santos, T., Nogueira Mendes, R., Vasco, a., 2016. Recreational activities in urban parks: Spatial interactions among users. J. Outdoor Recreat. Tour. 15, 1-9. doi:10.1016/j.jort.2016.06.001

Shafer, C.S., Lee, B.K., Turner, S., 2000. A tale of three greenway trails: User perceptions related to quality of life. Landsc. Urban Plan. 49, 163-178. doi:10.1016/S01692046(00)00057-8

Statistics Finland. (2015). Population largest munisipalities. Available from. http://www.hri.fi/en/dataset/helsingin-vtntymikan-sukupuolen-ja-imukaan-2004-alkaen 
Taczanowska, K., Muhar, A., Brandenburg, C., 2008. Potential and limitations of GPS tracking for monitoring spatial and temporal aspects of visitor behaviour in recreational areas. Proc. Fourth International Conference on Monitoring and Management of Visitor Flows in Recreational and Protected Areas. Available from: http://mmv.boku.ac.at/refbase/files/taczanowska karolin-2008-potential and limita.pdf

Tyrväinen, L., Mäkinen, K., Schipperijn, J., 2007. Tools for mapping social values of urban woodlands and other green areas. Landsc. Urban Plan. 79, 5-19. doi:10.1016/j.landurbplan.2006.03.003

Verlič, A., Arnberger, A., Japelj, A., Simončič, P., Pirnat, J., 2015. Perceptions of recreational trail impacts on an urban forest walk: A controlled field experiment. Urban For. Urban Green. 14, 89-98. doi:10.1016/j.ufug.2014.12.004

Walden-Schreiner, C., Leung, Y.F., 2013. Spatially characterizing visitor use and its association with informal trails in yosemite valley Meadows. Environ. Manage. 52, 163-178. doi:10.1007/s00267-013-0066-0

Wimpey, J., Marion, J.L., 2011. A spatial exploration of informal trail networks within Great Falls Park, VA. J. Environ. Manage. 92, 1012-1022. doi:10.1016/j.jenvman.2010.11.015

Wolf, I.D., Wohlfart, T., 2014. Walking, hiking and running in parks: A multidisciplinary assessment of health and well-being benefits. Landsc. Urban Plan. 130, 89-103. doi:10.1016/j.landurbplan.2014.06.006

Wolf, I.D., Wohlfart, T., Brown, G., Bartolomé Lasa, A., 2015. The use of public participation GIS (PPGIS) for park visitor management: A case study of mountain biking. Tour. Manag. 51, 112-130. doi:10.1016/j.tourman.2015.05.003

Zandbergen, P. a., 2009. Accuracy of iPhone locations: A comparison of assisted GPS, WiFi and cellular positioning. Trans. GIS 13, 5-25. doi:10.1111/j.1467-9671.2009.01152.x 